\title{
Teratological Effects of Gamma-Irradiation during three Gestaional Intervals in Rats
}

\author{
*Elham A. Al-Shaibani, **Nadia, H. Ismail, ***Omaima S. Eissa \\ Mohamed I. Rady and Zaki, T. Zaki \\ *Department of Biology- Faculty of Science, Sana'a University, **Department of Zoology, \\ Faculty of Grils, Ain Shams University, ***Radiation Biology Dept., National Center for \\ Radiation Research and Technology, Atomic Energy Authority and Department of Zoology, \\ Faculty of Science, Al-Azhar University
}

\begin{abstract}
Aim of the work: The present study aimed to evaluate the teratological effects of gamma-irradiation during three intervals of gestation; pre-implantation, organogenesis and fetal periods in rats.

Material and methods: Four groups of pregnant rats were used in this study; the first one (GI) served as control. The second (GII), third (GIII) and fourth (GIV) groups were subjected to whole body $\gamma$ radiation at a sub-lethal single dose level of $4 \mathrm{~Gy}$ at the third day, $10^{\text {th }}$ day and $14^{\text {th }}$ day of gestation respectively. Pregnant rats were sacrificed at the $20^{\text {th }}$ day of gestation, implantation sites, resorption, embryonic death, fetal death, growth retarded fetuses, external malformations and skeletal malformation were recorded.

Results: The results showed that whole body $\gamma$-irradiation caused resorption in the embryos of pregnant rats especially in those exposed during the pre-implantation period than the two other periods. The embryonic and fetal deaths were prominent in the fetuses maternally exposed to whole body $\gamma$-irradiation during the organogenesis period. The highest percentage of growth retarded fetuses was found in fetuses maternally exposed to $\gamma$-rays during the organogenesis period followed by fetuses maternally exposed to $\gamma$-irradiation during the fetal period and then fetuses maternally exposed to $\gamma$ irradiation during the pre-implantation period. The skeletal malformations as a result of $\gamma$-irradiation were mostly represented in less ossification in the skull bones, less ossification in the vertebral centra and wavy ribs. The most affected fetal skeleton was perceptive in GIII (fetuses maternally exposed to $\gamma$-irradiation during the organogenesis period) followed by GII and then GIV.
\end{abstract}

Keywords: $\gamma$-irradiation, Pregnant rats, Teratology

\section{Introduction:}

The teratogenic effects of embryonic and fetal irradiation are worth noting from point of view of biological indicators of radiation effect. Irradiation of mammalian embryos can produce a spectrum of morphological changes, ranging from temporary stunting of growth to severe organ defects and death (Brent, 1984; Uma Devi and Hande, 1990 and Bang et al., 2002). The effects on mean fetal birth weight of irradiation in utero with gamma rays at the different days of post coitus were wellestablished (Zhou and Wang, 1982; Michel and Fritz-Niggli, 1986, Sharma and Saini, 2003 and Jacquet, 2004).

Developing mammalian embryo is more sensitive to ionizing radiation than adult; many experimental studies have been shown that radiation-induced abnormalities in mammals are closely related to the period of development at which radiation is given (Saini et al., 1985; Croxatto et al., 1991; Sharma and Saini, 2003 and Maganha et al., 2006). During the first days (2-5) of development, the embryo remained isolated in the oviduct by the occlusion of isthmus-ampular and uterine-tubal junctions. In this region, there were nutrients and specific factors needed for its survival and development until the blastocyst phase, at which time the utero-tubal junction opened for the blastocyst to pass into the uterine cornua (Croxatto et al., 1991). Direct or indirect effects of xenobiotics including irradiation must cause alterations in the pre-implantation embryo development (Gu et al., 1997 and Maganha et al., 2006).

Nash and Gowen (1982) reported that the period of organogenesis is more radiosensitive than the fetal growth period as far as resorption, litter size and mortality of young ones are concerned and the gestation day 11.5 is close to stage of maximum susceptibility for growth retardation. Khera (1985) correlated the frequency of fetal malformations to the maternal toxicity as transient or permanent 
alterations in the maternal physiology with potential to cause adverse effects in the offspring during the embryonic and fetal development. Moreover, Devi et al. (1999) demonstrated that exposure of a mouse on fetal period of gestation to radiation doses induced significant impairment in the brain function, without producing any effects on brain morphology.

\section{Material And Methods}

Thirty-two adult virgin female rats (Rattus norvegicus) weighing (150-180 gm) and ten adult males were purchased from the Egyptian Organization for Vaccine and Biological Preparations at Helwan, Egypt. After two weeks period of acclimatization, female rats were distributed into four groups of eight animals in each per cage on a 12-h light/12-h dark cycle. All groups were placed in cages overnight with untreated males (in a ratio of 1 male to 3 females). Then, in each morning, vaginal smears were prepared and examined under the microscope. The presence of sperms in the vaginal smear during estrus denoted day zero of gestation (Anderson et al., 1989). The pregnant rats were divided as follow: the first group (GI), untreated, was sited as the control, the second group (GII) exposed to whole body $\gamma$-irradiation at the third day of gestation (preimplantation period). The third group (GIII) exposed to whole body $\gamma$-irradiation at the $10^{\text {th }}$ day of gestation (organogenesis period) and the fourth one (GIV) exposed to whole $\gamma$ irradiation at the $14^{\text {th }}$ day of gestation (fetal period). These periods were determined according to Maganha et al. (2006).

The whole body $\gamma$-irradiation was performed using Cesium 137 Biological $\gamma$-cell-40 irradiation facility belonging to The National Center for Radiation Research and Technology (NCRRT). Whole body $\gamma$-irradiation was delivered for the necessary calculated time for the sub-lethal dose level of 4 Gy (single dose). The dose rate was equal to $0.605 \mathrm{rad} / \mathrm{sec}$.

Pregnant rats were sacrificed at the $20^{\text {th }}$ day of gestation; uterine horns were opened and observed for the total number of implantation sites including resorption (rudimentary fleshy mass), embryonic death (partly formed embryo attached to the placental disc) and fetal death (fully formed dead fetus). Live fetuses were removed from the uterus and observed for the external anomalies, they weighed individually and the mean fetal weight of individual group litter was calculated. Body length was measured from the tip of the snout to the base of the tail and the longitudinal distance from the tip of the snout to the base of the skull was measured as head length. The distance between the two ears was recorded as head width. Growth retarded fetuses was calculated as the number of growth retarded fetuses/ total number of live fetuses (Bang et al., 2002). Alizarin red stain was used to detect any skeletal abnormalities according to the method described by Wessner (1968).

\section{Results}

The obtained data revealed that whole body $\gamma$ irradiation (4Gy single dose) caused resorption in the embryos of pregnant rats that represented by $15.78 \%$ in GII, $11.32 \%$ in GIII and $12.07 \%$ in GIV (Table 1). These results denoting that the resorption in embryos is more sensitive to $\gamma$-irradiation during the preimplantation period (GII) than the two other periods. The percentage of resorption in the control group (GI) was $7.14 \%$. The highest percentage of embryonic death was recorded in dams exposed to $\gamma$-rays during the organogenesis period (GIII), being $23.40 \%$. While in GII and GIV the percentages of embryonic death were $14.85 \%$ and $15.96 \%$ respectively (Table 1). Also, the highest percentage of fetal death was found in GIII (rats maternally exposed to $\gamma$-irradiation during the organogenesis period), being $17.02 \%$, while in GII and GIV the percentage of fetal death was $10.52 \%$ and $11.76 \%$ respectively. Representative isolated uteri of control and treated groups are illustrating in plate (1).

The lowest number of survived fetuses was found in GIII; represented by $52.83 \%$ only, followed by GII, represented by $61.40 \%$, and then GIV, represented by $63.79 \%$ (Table 1). The survived fetuses in the control animals were represented by $85.71 \%$ in proportion to the total number of implantation sites. The number of malformed fetuses was $2(4.17 \%), 8$ (22.86\%), $18(6428 \%)$ and $10(27.03 \%)$ in Control, GII, GIII and GIV respectively (Table 1). These results showed that the exposure to ionizing radiation during the organogenesis period produced the highest percentage of teratogenic effects than the other two periods; pre-implantation and fetal periods.

The average fetal weight of live fetuses recorded $1.48,1.39,1.27$ and $1.36 \mathrm{~g}$. in GI, GII, GIII and GIV respectively (Table 1). This 
average was significantly decreased $(\mathrm{P}<0.05)$ in GIII and non-significantly decreased in both GII and GIV, as compared with the control (GI). Also, each of fetal body length, head length and head width in GIII (rats maternally exposed to $4 \mathrm{~Gy}$ single dose during organogenesis period) showed significant decreases in comparison with the control. While, in GII and GIV there was a nonsignificant decrease in these mentioned measurements, as compared with the control (Table 1).

The incidences of external malformations in rat fetuses maternally exposed to $4 \mathrm{~Gy}$ single dose during three intervals of gestation are summarized in table (2). Two cases of exencephaly were noticed in GIII, and only one case was noticed in GIV. One case of anophthalamia was noticed in each of GIII and GIV. Two cases of microphthalamia were noticed only in GIII.

The abdominal hernia was noticed in each of GII, GIII and GIV; being $8.57 \%, 10.71 \%$ and $10.81 \%$ respectively. Also, the abdominal haematoma was $5.71,17.85$ and $8.11 \%$ in GII, GIII and GIV respectively against $4.17 \%$ in the control group. Two fetuses with micromelia were noticed only in GIII. Two fetuses with kinky tail were noticed in GII and only one in GIII. The clubfoot abnormality was noticed in each of GII, GIII and GIV; represented by $2.86 \%, 7.14 \%$ and $2.70 \%$ respectively. The highest percentage of growth retarded fetuses was found in GIII (fetuses maternally exposed to $\gamma$-irradiation during the organogenesis period) followed by GIV (fetuses maternally exposed to $\gamma$-irradiation during the fetal period) and then GII (fetuses maternally exposed to $\gamma$-irradiation during the preimplantation period). The percentage of growth retarded fetuses in the control was $4.17 \%$ (Table 2). The reduction in body weight and some morphological abnormalities are illustrated in plate (2).

The incidences of skeletal malformations indicated by Alizarin red stain in rat fetuses maternally exposed to 4Gy single dose during three intervals of gestation are illustrated in table (3). None of the 10 control fetuses showed any skeletal malformation or variation in their pattern of ossification. Less ossification in the skull bones of fetuses maternally exposed to gamma- irradiation was noticed; represented by $20.0 \%, 40.0 \%$ and $10.0 \%$ in GII, GIII and GIV respectively. Also, less ossification in the vertebral centra was noticed in the fetuses of $\gamma$-irradiated dams; the highest percentage was found in GIII being $33.3 \%$. Wavy ribs were noticed in GII, GIII and GIV, while only one fetus with fusion in ribs was noticed in GII, and one fetus with absence of ribs was noticed in GIII (Table 3). Absence of metacarpal bones was noticed in each of GII and GIII, while absence of metatarsal bones was noticed only in GIV. Missing of sternebral bones was prominent in GIII, represented by $20.0 \%$, while in each of GII and GIV it was represented by $10.0 \%$. Therefore, the most affected fetal skeleton was perceptive in GIII (fetuses maternally exposed to $\gamma$-irradiation during the organogenesis period) followed by GII and then GIV. Representative skeletal abnormalities are illustrated in plate (3).

\section{Discussion}

The present work was undertaken to study the comparative radiosensitivity of different gestational ages by assessing any detectable effects in full-grown rat fetuses. The present results showed that whole body $\gamma$-irradiation (4Gy single dose) caused resorption in the embryos of pregnant rats that represented by $15.78 \%$ in GII, $11.32 \%$ in GIII and $12.07 \%$ in GIV. These results denoting that the resorption in embryos is more sensitive to $\gamma$-irradiation during the pre-implantation period (GII) than the two other periods. In agreement with Kim et al. (2001) the present results on preimplantation exposure to $\gamma$ - rays showed that the morula stages had high sensitivity to a lethal radiation dose. In contrary, Sharma and Saini (2003) found a complete embryonic resorptrions on day 9 and complete and partial resorption on day 11 of gestation after in utero exposure to $2 \mathrm{~Gy}$ gamma rays in mice.

The present study revealed that the maximum lethality in the embryos and fetuses was occurred in dams irradiated during the period of organogenesis. In coincidence, Sharma and Saini (2002) reported that during the period of major organogenesis, mammalian embryos are highly susceptible to radiation-induced gross anatomic abnormalities; this period spans 7 to 12 days post-coitus in mice, corresponding to about 14 to 15 days in humans and form 6 to 12 in rats. Also, Muller et al. (1994) stated that the sensitivity to radiation killing decreased as the blastocyst progressed, but again there was a period of high sensitivity during the 
organogenesis period. Whoever, lethality has been recognized as the main effect of irradiation during the pre-implantation period. It has also long been admitted that embryos escaping killing by radiation would develop without anomaly, due to the fact that the cells are still undifferentiated at these stages and that loss of one or a few cells can eventually be compensated by other cells (Kim et al., 2001). Gamma-irradiation during the intrauterine development can produce a broad spectrum of congenital abnormalities, growth retardation, developmental delays, and functional deficits (Lyon and Renshaw 1988 and Kiskova and Smajda, 2006). The present results revealed that $\gamma$-irradiation induced reduction in the mean fetal weight, head length and head width; this reduction was significant only in the fetuses of pregnant rats irradiated during the period of organogenesis. According to Holemans et al. (2003) and Ergaz et al. (2005) the fetus's body weight reduction could be related to nutrition, maternal metabolism and placental vascularizations. Also, as observed by Holemans et al. (2003), alterations in the early embryos might become apparent in fetuses or in adulthood. In agreement with the present results, a significant decrease in head size was a feature observed after irradiation of mice at day 11.5 post coitus with both $\mathrm{x}$-rays and gamma-rays (Uma Devi and Hande, 1990 and Uma Devi et al. 1994).

Streffer and Muller (1996) discussed that exposure to ionizing radiation of the early developmental stages further induced a general destabilization of the genome so that noxes acting on the fetus (e.g. insufficient nutrition or oxygen supply and harmful metabolites) will be more successful in evoking detrimental effects. Derradji et al. (2008) examined the external abnormalities caused by irradiation of mouse embryos during late organogenesis (day 12 post conception); the only gross malformations observed were forelimb defects combined with dwarfism and general oedema. The present results showed that whole body $\gamma$ irradiation (4Gy single dose) during pregnancy in rats resulted in different external fetal malformations. The most prominent malformations were mostly represented in abdominal haematoma and abdominal hernia that were found in all irradiated groups. Meanwhile, cases of exencephaly, unilateral anophthalmia, microphthalmia, micromelia, kinky tail, clubfoot were recorded. No cases of cleft lip were recorded in this study.

However, the highest percentage of growth retarded fetuses was recorded in GIII (fetuses maternally exposed to $\gamma$-irradiation during the organogenesis period) followed by GIV (in utero exposure during the fetal period) and then GII (fetuses maternally exposed to $\gamma$ irradiation during the pre-implantation period). In agreement, earlier study has been showed that single dose of $x$-radiation induced bilateral anophthalmia and microphyhalmia in rats (Woollam et al., 1967). Streffer and Muller (1996) reported that the most pronounced malformations were abdominal hernia and a case of exencephaly in mice fetuses maternally exposed to 3.5 Gy of $\gamma$-rays during the preimplantation period. Also, Kim et al. (2001) reported that tail abnormalities and abnormalities of the extremities were prominent upon exposure during the organogenesis period. Jacquet (2004) studied the incidence of congenital anomalies in mice due to ionizing radiation and found that reduced body size and exencephaly (often associated with exophthalmia or open eyelids) were the most frequent anomalies. The previous author discussed that the mechanism causing malformation is the cellular death followed by an arrest of development of the structure at any early stage; and apparition of a malformation will depend on the number of damaged cells in the forming organ.

Many embryological studies have been done about skeletal changes in the fetuses of dams under the effect of radiation. The present results revealed that the high incidence of skeletal abnormalities was mostly obvious in the rat fetuses of dams exposed to whole boy $\gamma$-irradiation during the organogenesis period followed by pre-implantation period and then fetal period. The most skeletal malformations observed in the present study due to in utero exposure to gamma-irradiation were less ossification in the skull bones and less ossification in the vertebral sternbrae. Sharma and Saini (2002) reported that skeletal elements of mice fetuses maternally exposed to gamma rays showed very poor ossification in the system after exposure during organogenesis followed by fetal and preimplantation periods. The authors discussed that this probably accounted for the reduction in body weight in the same sequence; the highest reduction in body weight was observed 
after exposure during the organogenesis period.

In agreement with the present results, Baskar and Uma Devi (2002) reported that even exposure to a lower dose of $0.35 \mathrm{~Gy}$ during the late organogenesis days 11.5 and 12.5 post coitus produced significant reduction in locomotors and exploratory activities in mice. Also, Satow et al. (1989) reported that malformations in rat fetuses were observed at the highest frequency in the group exposed to irradiation on day 8 after coitus. Kim et al. (2001) indicated that the late organogenesis period was a particularly sensitive phase in the development of the brain, skull and extremities of mouse. Skeletal abnormalities were prominent upon exposure during the organogenesis period.

In conclusion, the results presented in this study indicated that the organogenesis period was a particularly sensitive phase in the development of the fetal rats specially skull, ribs and extremities. Finally, the results showed that $\gamma$-irradiation is a teratogenic agent as was strongly suspected.

\section{References:}

1- Anderson M, Hagiwara A, Kovatch R, Ehm S and Rice J M (1989): Transplacental initiation of liver, lung, neurogenic and connective tissue tumors by $\mathrm{N}$-nitroso compound in mice. Fund. Appl. Toxicol., 12(3): 604-620.

2- Bang D, Leej H, Kim S, Kim T, Lee Y, Lee C and Kim S (2002): Dose-incidence relationship on the prenatal effects of Gamm-radiation in mice. J. Vet. Sci., 3(1): 7-11.

3- Baskar R and Uma Devi P (2002): Influence of gestational age to low-level gamma irradiation on postnatal behavior in mice. Neurotoxicol. Teratol., 22(4): 593-602.

4- Brent R D (1984): The effects of ionizing radiation, microwaves and ultrasound on the developing embryo: Clinical interpretations and applications of the data. Curr Proble. Pediatr., 14: 1-87.

5- Croxatto H B, Ortiz M E, Forcelledo M L, Fuentealba B and Noe G (1991): Hormonal control of ovum transport through the rat oviduct. Arch. Biol. Med. Grap., 24: 403-410.

6- Derradji H, Bekaret S and De Meyer A (2008): Ionizing radiation-induced gene modulations, cytokine content changes and telomere shortening in mouse fetuses exhibiting forelimb defects. Develop. Biol., 322: 302-313.

7- Devi E, Hossain P and Bisht K (1999): Effect of late fetal irradiation on adult behavior of mouse: Dose-response relationship. Neurotoxicol. Teratol., 21(2): 193-198.

8- Ergaz Z, Avgil M and Ornoy A (2005): Intrauterine growth restriction-etiology and consequences: What do we know about the human situation and experimental animal models? Toxicology, 20: 301322.

9- Gu Y, Kai M and Kusama T (1997): The embryonic and fetal effects in ICR mice irradiated in the various stages of the pre-implantation period. Radiat. Res., 147: 735-740.

10- Holemans K, Aerts L and Van Assche F A (2003): Fetal growth restriction and consequences for the offspring in animal models. J. Soc. Gynecol. Investig., 10: 392-399.

11- Jacquet P (2004): Sensitivity of germ cells and embryos to ionizing radiation. J. Biol. Regul. Homeost. Agents, 18: 106-114.

12- Khera K S (1985): Maternal toxicity- a possible etiological factor in embryo-fetal death and fetal malformations of rodent-rabbit species. Teratology, 31: 129-153.

13- Kim S, Lee J, Oh H, Kim S, Lee C, Kee S, Kim T and Lee S (2001): Dependence of malformation upon gestational age and exposed dose of gamma radiation. J. Radiat. Res., 42: 255-264.

14- Kiskova J and Smajda B (2006): Behavioural changes in prenatal rats irradiated with dosage of $\gamma$ rays. Bull. Vet. Inst. Pulawy., 50: 595-598.

15- Lyon M F and Renshaw R (1988): Induction of congenital malformation in mice by parental irradiation. Mutat. Res., 198: 277283.

16- Maganha J, Souza E, Marcos R, Brando A, Peters V and Guerra M (2006): Development Alteration in Rats Treated with lapachol. Braz. Arch. Biol. Technol., 49(6): 927-934.

17- Michel C and Fritz-Niggli H (1986): Teratogenic interaction between cadmium and radiation in mice. Experientia, 42: 80.

18- Muller W U, Streffer C and Pampfer S (1994): The question of threshold doses for radiation damage: malformations induced by radiation exposure of unicellular or multicellular preimplantation stages of mouse. Radiat. Environ. Biophys., 33: 63-68.

19- Nash D J and Gowen J W (1982): Effects of Xirradiation upon postnatal growth in mouse. Biol. Bull., 122: 115

20- Saini M, Kumar S and Saini N (1985): Liv.53 protection against radiation-induced abnormalities on mammalian prenatal development. Radiobiol. Radiother., 26: 385-388.

21- Satow Y, Lee Y, Horii H, Okudo H, Tsuchimoto S, Sawada S, and Yokoro K (1989): Teratogenic Effect of Californium-252 Irradiation in Rats. Radiat. Res. 30: 155-163.

22- Sharma P and Saini M R (2002): Growth retardation in fetus and offspring of Swiss albino mice after intrauterine exposure to tritiated water. Ind. J. Nuc. Med., 17(2 \& 3): 57-63.

23- Sharma P and Saini M R (2003): Modification of radiation induced mortality by cysteamine, MPG and their combination in Swiss albino mice. Ind. J. Nuc. Med., $18(1 \& 2)$ : 12-18.

24- Streffer C and Muller W (1996): Malformations after radiation exposure of pre-implantation stages. Int. J. Dev. Biol., 40: 355-360.

25- Uma Devi P and Hande M P (1990): Effect of low dose $70 \mathrm{kVp} \quad \mathrm{X}$-rays on the intrauterine development of mice. Experimentia, 46: 511-513.

26- Uma Devi P, Baskar R and Hande M P (1994): 
Teratological Effects of Gamma-Irradiation during.....

Effect of exposure to low-dose gamma radiation during late organogenesis in the mouse fetus. Radiat. Res. 138: 133-138.

27- Wessner F M (1968): General zoological microtechniques. Scientific Book Agency, Calcutta, pp. 100-101.
28- Woollam D, Pratt C and Fozzard J (1967): Influence of vitamins upon some teratogenic effect of radiation. Brit. Med. J., 25:1219-1221.

29- Zhou J and Wang J (1982): Studies of radiation on mouse embryos in the pre-implantation stage. Chin. J. Radiol. Med. Prot., 2: 18.

Table 1: Embryonic and fetal death and fetal body weight of gamma-irradiated rats.

\begin{tabular}{|c|c|c|c|c|}
\hline & Control (GI) & GII & GIII & GIV \\
\hline No. of dams & 8 & 8 & 8 & 8 \\
\hline $\begin{array}{c}\text { Implantation } \\
\text { sites }\end{array}$ & 56 & 57 & 53 & 58 \\
\hline Resorption & $\begin{array}{c}4 \\
(7.14 \%) \\
\end{array}$ & $\begin{array}{c}9 \\
(15.78 \%)\end{array}$ & $\begin{array}{c}6 \\
(11.32 \%) \\
\end{array}$ & $\begin{array}{c}7 \\
(12.07 \%) \\
\end{array}$ \\
\hline Embryonic death & $\begin{array}{c}3 \\
(5.77 \%) \\
\end{array}$ & $\begin{array}{c}7 \\
(14.85 \%) \\
\end{array}$ & $\begin{array}{c}11 \\
(23.40 \%) \\
\end{array}$ & $\begin{array}{c}8 \\
(15.96 \%) \\
\end{array}$ \\
\hline Fetal death & $\begin{array}{c}1 \\
(1.92 \%) \\
\end{array}$ & $\begin{array}{c}6 \\
(10.52 \%) \\
\end{array}$ & $\begin{array}{c}8 \\
(17.02 \%) \\
\end{array}$ & $\begin{array}{c}6 \\
(11.76 \%) \\
\end{array}$ \\
\hline No. of live fetuses & $\begin{array}{c}48 \\
(85.71 \%) \\
\end{array}$ & $\begin{array}{c}35 \\
(61.40 \%) \\
\end{array}$ & $\begin{array}{c}28 \\
(52.83 \%) \\
\end{array}$ & $\begin{array}{c}37 \\
(63.79 \%) \\
\end{array}$ \\
\hline $\begin{array}{l}\text { No. of malformed } \\
\text { fetuses }\end{array}$ & $\begin{array}{c}2 \\
(4.17 \%)\end{array}$ & $\begin{array}{c}8 \\
(22.86 \%)\end{array}$ & $\begin{array}{c}18 \\
(64.28 \%)\end{array}$ & $\begin{array}{c}10 \\
(27.03 \%)\end{array}$ \\
\hline $\begin{array}{l}\text { Mean fetal weight } \\
\text { (g) } \pm \text { SD }\end{array}$ & $\begin{array}{c}1.48 \\
\pm 0.427\end{array}$ & $\begin{array}{c}1.39 \\
\pm 0.420\end{array}$ & $\begin{array}{c}1.27^{*} \\
\pm 0.325\end{array}$ & $\begin{array}{c}1.36 \\
\pm 0.334\end{array}$ \\
\hline $\begin{array}{l}\text { Mean fetal body } \\
\text { length }(\mathrm{cm}) \pm \text { SD }\end{array}$ & $\begin{array}{c}1.48 \\
\pm 0.427\end{array}$ & $\begin{array}{c}1.39 \\
\pm 0.420\end{array}$ & $\begin{array}{c}1.27 * \\
\pm 0.325\end{array}$ & $\begin{array}{c}1.36 \\
\pm 0.334\end{array}$ \\
\hline $\begin{array}{l}\text { Mean fetal head } \\
\text { length }(\mathrm{cm}) \pm \text { SD }\end{array}$ & $\begin{array}{c}1.223 \\
\pm 0.184\end{array}$ & $\begin{array}{c}1.217 \\
\pm 0.132\end{array}$ & $\begin{array}{l}1.142^{*} \\
\pm 0.138\end{array}$ & $\begin{array}{c}1.198 \\
\pm 0.156\end{array}$ \\
\hline $\begin{array}{l}\text { Mean fetal head } \\
\text { width }(\mathrm{cm}) \pm \text { SD } \\
\end{array}$ & $\begin{array}{c}0.856 \\
\pm 0.141 \\
\end{array}$ & $\begin{array}{r}0.810 \\
\pm 0.157 \\
\end{array}$ & $\begin{array}{l}0.782^{*} \\
\pm 0.144 \\
\end{array}$ & $\begin{array}{c}0.806 \\
\pm 0.142 \\
\end{array}$ \\
\hline
\end{tabular}

$*=$ significant $(\mathrm{P} \leq 0.05)$ 
Elham A. Al-Shaibani etal .,...

Table 2: Incidence of external malformations in fetuses of gamma-irradiated rats.

\begin{tabular}{|c|c|c|c|c|}
\hline \hline Fetuses examined & $\begin{array}{c}\text { Control } \\
(\text { GI })\end{array}$ & GII & GIII & GIV \\
\hline Exencephaly & 0 & 35 & 28 & 37 \\
\hline Anophthalmia & 0 & 0 & $\begin{array}{c}2 \\
(7.14 \%)\end{array}$ & $\begin{array}{c}1 \\
(2.70 \%)\end{array}$ \\
\hline Microphthalmia & 0 & 0 & $\begin{array}{c}1 \\
(3.57 \%)\end{array}$ & $\begin{array}{c}2 \\
(2.70 \%)\end{array}$ \\
\hline $\begin{array}{c}\text { Abdominal hernia } \\
\text { Abdominal } \\
\text { haematoma }\end{array}$ & 0 & $\begin{array}{c}3 \\
(8.57 \%)\end{array}$ & $\begin{array}{c}3 \\
(10.71 \%)\end{array}$ & $\begin{array}{c}4 \\
(10.81 \%)\end{array}$ \\
\hline Micromelia & 0 & $\begin{array}{c}2 \\
(5.71 \%)\end{array}$ & $\begin{array}{c}5 \\
(17.85 \%)\end{array}$ & $\begin{array}{c}3 \\
(8.11 \%)\end{array}$ \\
\hline Kinky tail & 0 & 0 & $\begin{array}{c}2 \\
(7.41 \%)\end{array}$ & 0 \\
\hline Clubfoot & 0 & $\begin{array}{c}1 \\
(5.71 \%)\end{array}$ & $\begin{array}{c}1 \\
(3.57 \%)\end{array}$ & 0 \\
\hline $\begin{array}{c}\text { \% of growth } \\
\text { retarded fetuses }\end{array}$ & $4.17 \%$ & $22.86 \%$ & $\begin{array}{c}2 \\
(7.14 \%)\end{array}$ & $\begin{array}{c}1 \\
(2.70 \%)\end{array}$ \\
\hline \hline
\end{tabular}

Growth retarded fetuses $=$ No. of retarded $/$ total No. of live fetuses. 
Table 3: Incidence of skeletal malformations in gamma-irradiated rats

\begin{tabular}{||c|c|c|c|c|}
\hline Fetuses examined & $\begin{array}{c}\text { Control } \\
(\text { GI })\end{array}$ & GII & GIII & GIV \\
\hline $\begin{array}{c}\text { Less ossification in the } \\
\text { skull bones }\end{array}$ & 0 & 10 & 10 & 10 \\
\hline $\begin{array}{c}\text { Less ossification in the } \\
\text { vertebral centra }\end{array}$ & 0 & $\begin{array}{c}2 \\
(20.0 \%)\end{array}$ & $\begin{array}{c}2 \\
(40.0 \%)\end{array}$ & $\begin{array}{c}1 \\
(10.0 \%)\end{array}$ \\
\hline $\begin{array}{c}\text { Wavy ribs } \\
\text { Fusion of ribs }\end{array}$ & 0 & $\begin{array}{c}3 \\
(10.0 \%)\end{array}$ & $\begin{array}{c}2 \\
(33.3 \%)\end{array}$ \\
\hline $\begin{array}{c}\text { Absence of ribs } \\
\text { Absence of } \\
\text { metacarpal bones }\end{array}$ & 0 & $\begin{array}{c}2 \\
(10.0 \%)\end{array}$ & $\begin{array}{c}1 \\
(10.0 \%)\end{array}$ \\
\hline $\begin{array}{c}\text { Absence of metatarsal } \\
\text { bones }\end{array}$ & 0 & 0 & 0 & 0 \\
\hline Missing of sternebrae & 0 & $\begin{array}{c}1 \\
(10.0 \%)\end{array}$ & $\begin{array}{c}1 \\
(10.0 \%)\end{array}$ & 0 \\
\hline $\begin{array}{c}\text { Total no. of } \\
\text { malformations }\end{array}$ & 0 & 8 & 0 & 1 \\
\hline
\end{tabular}

The data presented in Tables 3 indicate that a malformed fetus usually had more than one anomaly. 

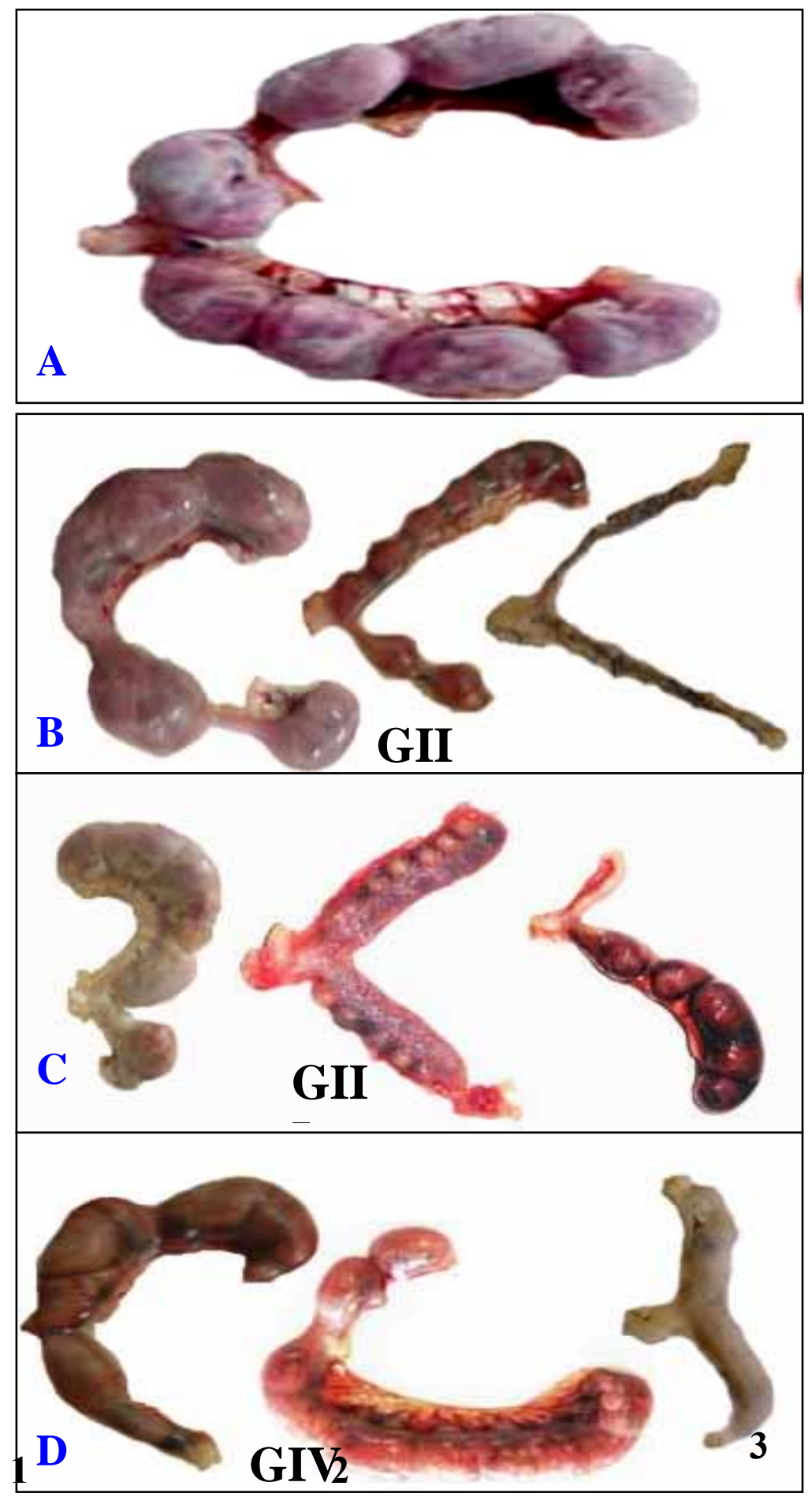

Plate 1: A: Photomicrograph of a uterus isolated from control rat showing equal distribution of the fetuses. B: Photomicrograph of uteri isolated from GII showing unequal distribution of the fetuses (1), fetal death (2) and embryonic death (3). C: Photomicrograph of uteri isolated from GIII showing unequal distribution of the fetuses (1), embryonic death (2) and fetal death (3). D: Photomicrograph of uteri isolated from GIV showing unequal distribution of the fetuses (1), embryonic death (2) and complete resorption (3). 

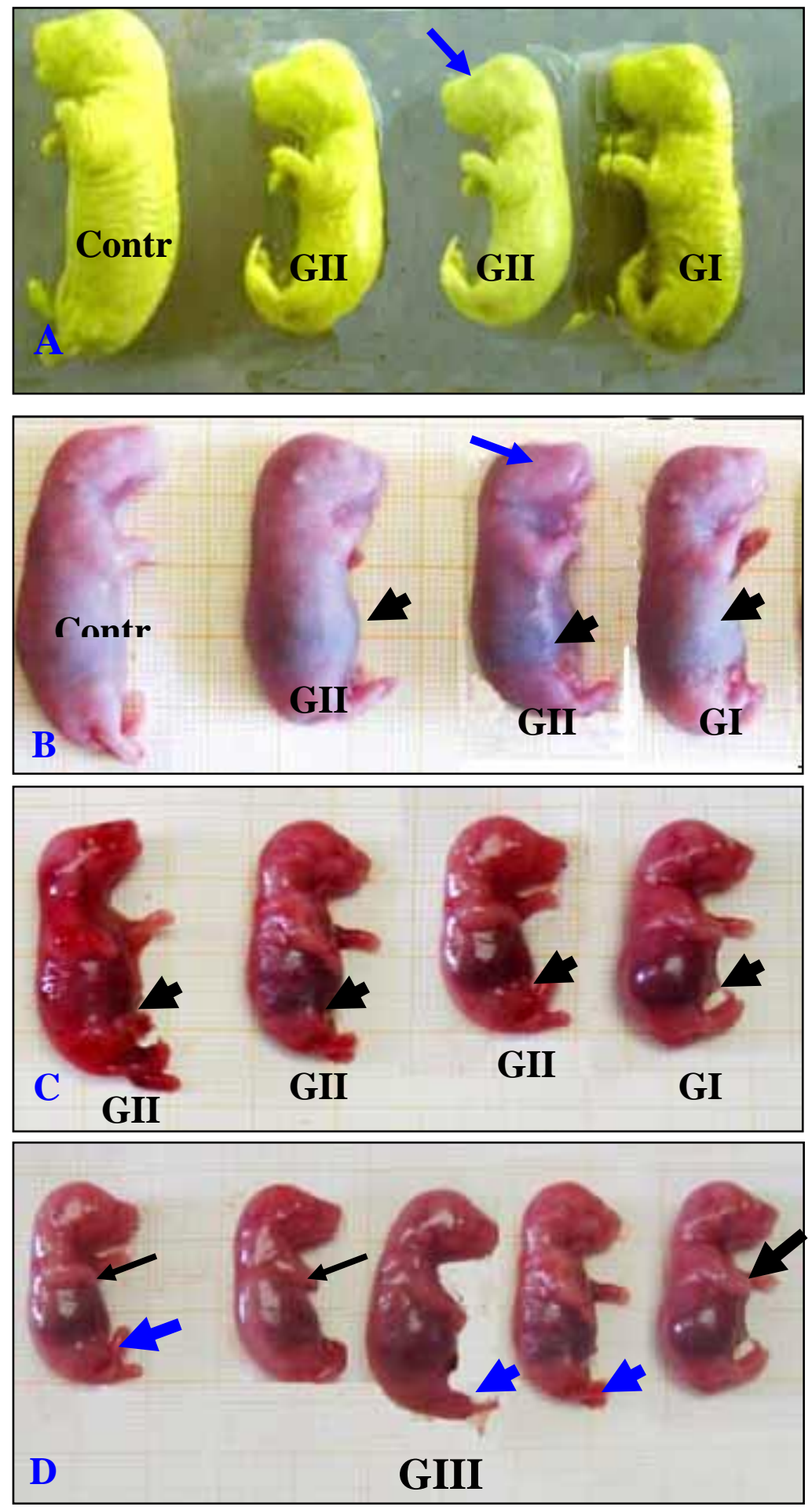

Plate 2: A: Photomicrograph of fetuses showing reduction in body weight, note microphthalmia in GIII. B: Photomicrograph of fetuses showing abdominal haematoma in all exposed groups, note anophthalmia in GIII. C: Photomicrograph of fetuses showing abdominal hernia. D: Photomicrograph of fetuses of GIII showing micromelia; forelimb (black arrows) and hind limb (blue arrows). 

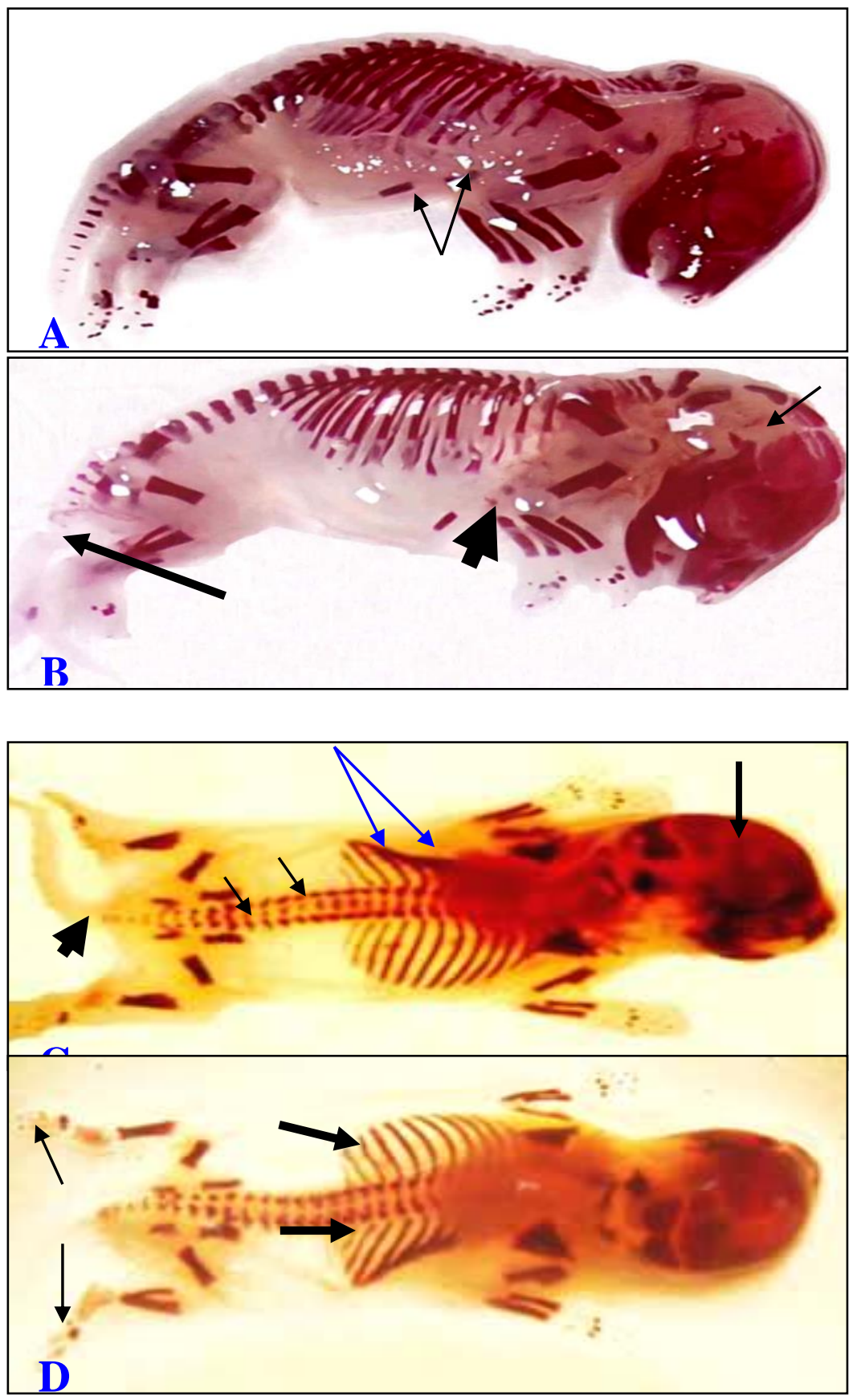

Plate 3: Skeletal system of fetuses stained with alizarin red. A: Photomicrograph of a control rat fetus showing normal ossification of the skeleton, note the normal strenbrae (arrow). B: Photomicrograph of a rat fetus of GII showing less ossification in the skull (thin arrow), less ossification of the sternabrae (thick arrow) and less ossification of the caudal vertebrae (long arrow). C: Photomicrograph of a rat fetus of GIII showing less ossification in the skull (long arrow), unilateral wavy ribs (blue arrows), less ossification of the vertebral centra (thin arrows) and less ossification of the caudal vertebrae (short arrow). D: Photomicrograph of a rat fetus of GIV showing missing in the metatarsal bones (thin arrows) and bilateral wavy ribs (thick arrow). 


\section{التأثيرات المشوهة لأشعة جاما أثخاء ثلاث فترات مختلفة من الحمل فى الجرذان

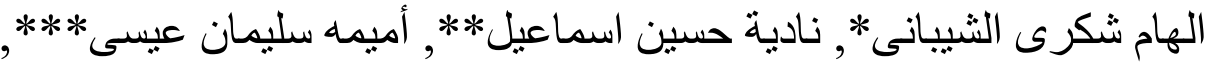

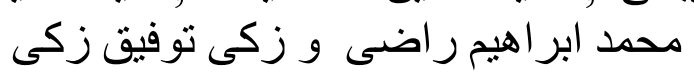

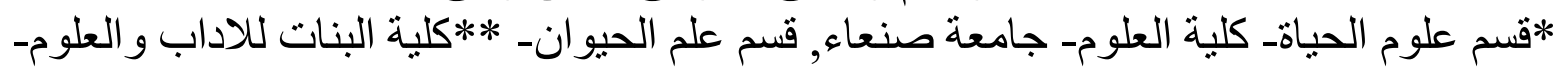

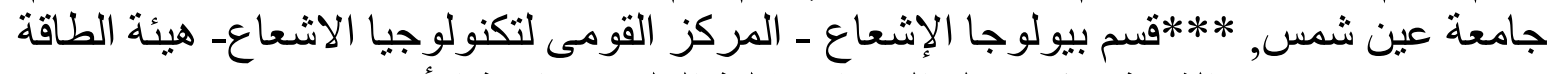

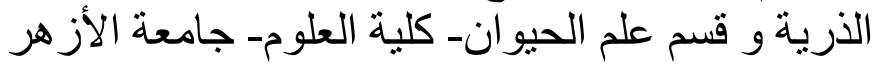

تضمن هذا البحث دراسة التأثير ات الماسخة لأشعة جاما أثناء ثلاث فترات مختلفة من الحمل (مرحلة قبل

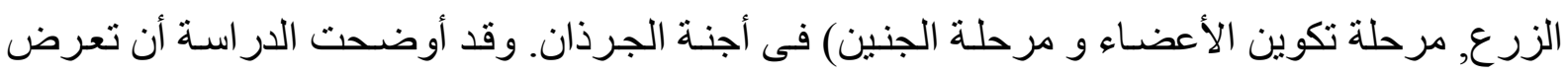

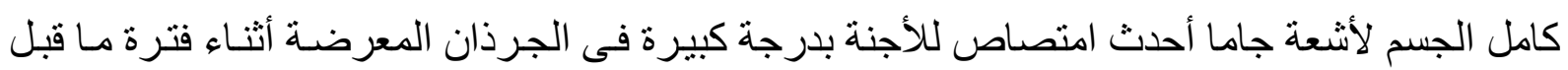

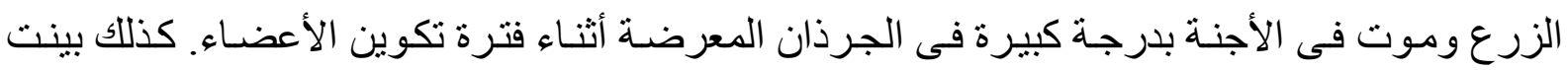

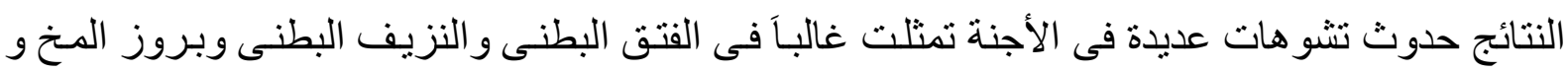

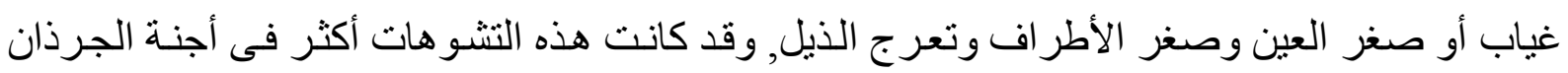
المعرضة للأشعة أثناء فترة تكوين الأعضاء. وقد أوضحت نتائج فحص الهيكل العظمى للأجنة حدوث نقص واضح لعملية التعظم فى الجمجمة ومر اكز

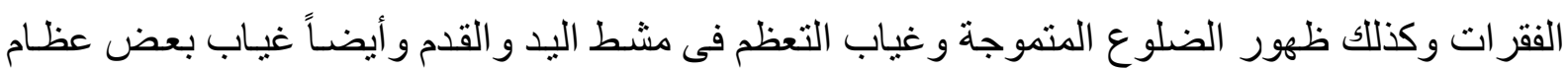

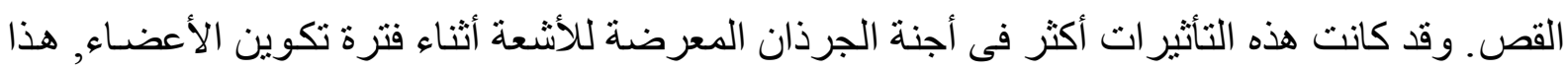

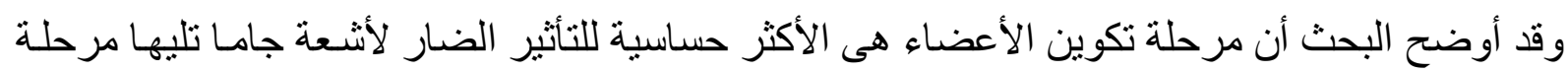
ماقبل الزرع. 